\title{
Teleconnections between the Peruvian Central Andes and Northeast Brazil during Extreme Rainfall Events in Austral Summer
}

\author{
JUAN SULCA \\ Department of Atmospheric and Environmental Sciences, University at Albany, State University of New York, Albany, \\ New York, and Instituto Geofisico del Peru, Lima, Peru \\ MATHIAS VuiLle \\ Department of Atmospheric and Environmental Sciences, University at Albany, State University of New York, \\ Albany, New York \\ YAMINA SILVA AND KEN TAKAHASHI \\ Instituto Geofisico del Peru, Lima, Peru
}

(Manuscript received 3 March 2015, in final form 12 August 2015)

\begin{abstract}
Extreme precipitation events in the Peruvian Andes have significant socioeconomic impacts, yet their atmospheric dynamics are poorly understood. Here austral summer (December-March) wet and dry spells and their continental- and large-scale teleconnections are analyzed using reanalysis, gridded, and in situ precipitation data. Dry and wet spells in the Peruvian Andes show a pervasive dipole pattern with precipitation anomalies of the opposite sign over northeastern Brazil. Composite anomalies of various atmospheric fields during extreme precipitation events indicate that this dipole is related to large-scale adjustments in the uppertropospheric Bolivian high-Nordeste low system, which in turn are modulated by northward-propagating extratropical Rossby wave trains. At upper- and midtropospheric levels, westerly wind anomalies over the Peruvian Andes suppress moisture flux from the Amazon during dry events, while wet events are characterized by opposite conditions. Yet, while easterly wind anomalies appear to be a prerequisite for heavy precipitation events in the region, they are not a sufficient forcing, as dry days can still occur during such periods. Dry spells in the Peruvian Andes appear to be linked to weakened convective activity over the western tropical Pacific, consistent with the previously documented El Niño influence over the region. Extreme dry and wet spells in northeastern Brazil only show a weak link to precipitation anomalies of the opposite sign over Peru but are strongly coupled with changes in the position and strength of the Nordeste low and the South Atlantic convergence zone.
\end{abstract}

\section{Introduction}

The Andes are considered the longest continental mountain chain in the world, running continuously near the western coast of South America from Colombia $\left(10^{\circ} \mathrm{N}\right)$ to the southern tip of the continent $\left(57^{\circ} \mathrm{S}\right)$. The mean maximum (peak) height of the Andes is in excess of $4000 \mathrm{~m}$ MSL along its tropical and subtropical portions (Garreaud 2009). The Andes are exposed to the

Corresponding author address: Mathias Vuille, Department of Atmospheric and Environmental Sciences, University at AlbanySUNY, ES 311, 1400 Washington Ave., Albany, NY 12222.

E-mail: mvuille@albany.edu tropical and extratropical upper-level large-scale circulation, characterized by moderate easterly winds at low latitudes (north of $15^{\circ} \mathrm{S}$ ) and westerly winds from sub- to extratropical latitudes. To the west of the central Andes, the South Pacific subtropical anticyclone produces dry and stable conditions, with moist air confined below the subsidence inversion around $900 \mathrm{hPa}$ (Garreaud et al. 2009), whereas the lowlands to the east of the Andes are controlled by a heat low and high humidity prevails in the lower and midtroposphere.

Almost $80 \%$ of the annual precipitation total (350$400 \mathrm{~mm}$ ) in the central Andes falls during the austral summer [December-March (DJFM)] when mid- and upper-level easterly winds, which are caused by a 
strengthening of the Bolivian high (BH), entrain nearsurface upslope easterly flow. This flow is responsible for moist air influx from the Amazon basin onto the central Andes, feeding convective storms (Garreaud 1999, 2000; Vuille 1999; Vuille et al. 2000; Vuille and Keimig 2004; Garreaud et al. 2003).

The Mantaro basin (MB) is located in the central Peruvian Andes $\left(10^{\circ} 34^{\prime}-13^{\circ} 35^{\prime} \mathrm{S}, 73^{\circ} 55^{\prime}-76^{\circ} 40^{\prime} \mathrm{W}\right)$ covering an area of approximately $34550 \mathrm{~km}^{2}$ (Fig. 1). It is a complex Andean region with altitudes ranging from 500 to $5350 \mathrm{~m} \mathrm{MSL}$, and its average altitude is $3800 \mathrm{~m}$ MSL. Precipitation is one of the most important climatological variables in the Mantaro basin because of its role in socioeconomic activities such as agriculture, energy generation, potable water supply, etc. The main rainy season occurs during the austral summer and is associated with easterly winds at upper levels whereas the dry season is associated with westerly winds (Instituto Geofísico del Perú 2005a). Occasionally, the Mantaro basin registers extreme hydrometeorological events during the wet season, such as dry or wet spells, frosts, flooding, and hailstorms. These extreme episodes have a short duration of a few days but are associated with strong negative impacts on the local population and economy. For example, dry spells, frosts, and hailstorms lead to damage of local crops, while wet spells and flooding cause landslides and damage to infrastructure. However, the knowledge about the physical mechanisms and origins of these extreme hydrometeorological events in the Mantaro basin is currently very poor.

Most work so far has instead focused on analyzing trends in rainfall for a few selected areas in Peru. For example, Haylock et al. (2006) documented a trend toward an increase in wet extremes in Ecuador and northern Peru, while a decrease was observed in southern Peru. For the Mantaro basin, Silva et al. (2008) documented a negative trend of $2 \%$ decade $^{-1}$ for annual rainfall and $4 \%$ decade $^{-1}$ for wet season rainfall since the second half of the 1980s and during the 1990s. Recently, Lavado Casimiro et al. (2013) expanded these analyses to other regions of the Peruvian Andes but did not find a robust trend in rainfall for the period 19652007, consistent with similar results by Vuille et al. (2003). However, none of these studies attempted an analysis of the relationship between rainfall extremes and the large-scale circulation.

Considerable attention has also been given to future changes in precipitation extremes. For example, Marengo et al. (2009) reported a positive tendency in heavy rainfall events [rainfall in the 95th percentile (R95p)] over the southern Peruvian Andes under climate change scenarios using a regional climate model (RCM). However, as in the few existing observational studies, no attempt to investigate the underlying physical mechanisms or relationships to the large-scale circulation was made. The advantage of establishing such links would be that the relationship between local meteorological variables and the large-scale circulation might allow the development of empirical statistical downscaling (ESD) models (e.g., Benestad et al. 2008), which could be employed in future climate change assessments of the region.

The ESD techniques use relationships between largescale fields (predictors) and local-surface variables (predictands) that have been derived from observed data and apply these to equivalent large-scale fields simulated by climate models (Christensen et al. 2007). The most critical step associated with the development of ESD models is the selection of the large-scale predictors (Hofer et al. 2015). More precisely, the predictor selection refers to the choice of 1) the large-scale model, 2) the model grid points or spatial area (i.e., the downscaling domain), and 3) the physical variable type. Defining these criteria has become more complicated because of the increasing availability of Earth system models and output variables.

Motivated by these considerations, the central objective of this study is thus to characterize wet and dry spells in the Mantaro basin and assess their teleconnections over South America during austral summer. The main expectation of our study is that the results will contribute to the development of statistical downscaling techniques for extreme rainfall events in Peru.

In the following section, the scientific background for our study is described. Section 3 discusses the data and methods that were applied. Section 4 presents the results from the analysis of wet and dry spells during DJFM over the Mantaro basin and northeastern Brazil (NEB), respectively. The last section discusses the results presented in the previous sections, summarizes this study, and ends with some concluding remarks.

\section{Background}

During austral summer, the atmospheric circulation in South America is characterized by the mature phase of the South American monsoon system and the strengthening of deep convection over the south-central Amazon (Vera et al. 2006; Garreaud et al. 2009; Marengo et al. 2012).

In the upper troposphere $(200 \mathrm{hPa})$, the $\mathrm{BH}$ and Nordeste low (NL) system is the main feature over South America during the austral summer (Fig. 2). The $\mathrm{BH}$ is a closed anticyclone, which forms in response to latent heat released during deep convection over the Amazon basin. It was initially identified by Gutman and Schwerdtfeger (1965) and Virji (1981) and linked to the 




FIG. 1. Location of MB, NEB (black box), and stations used. 


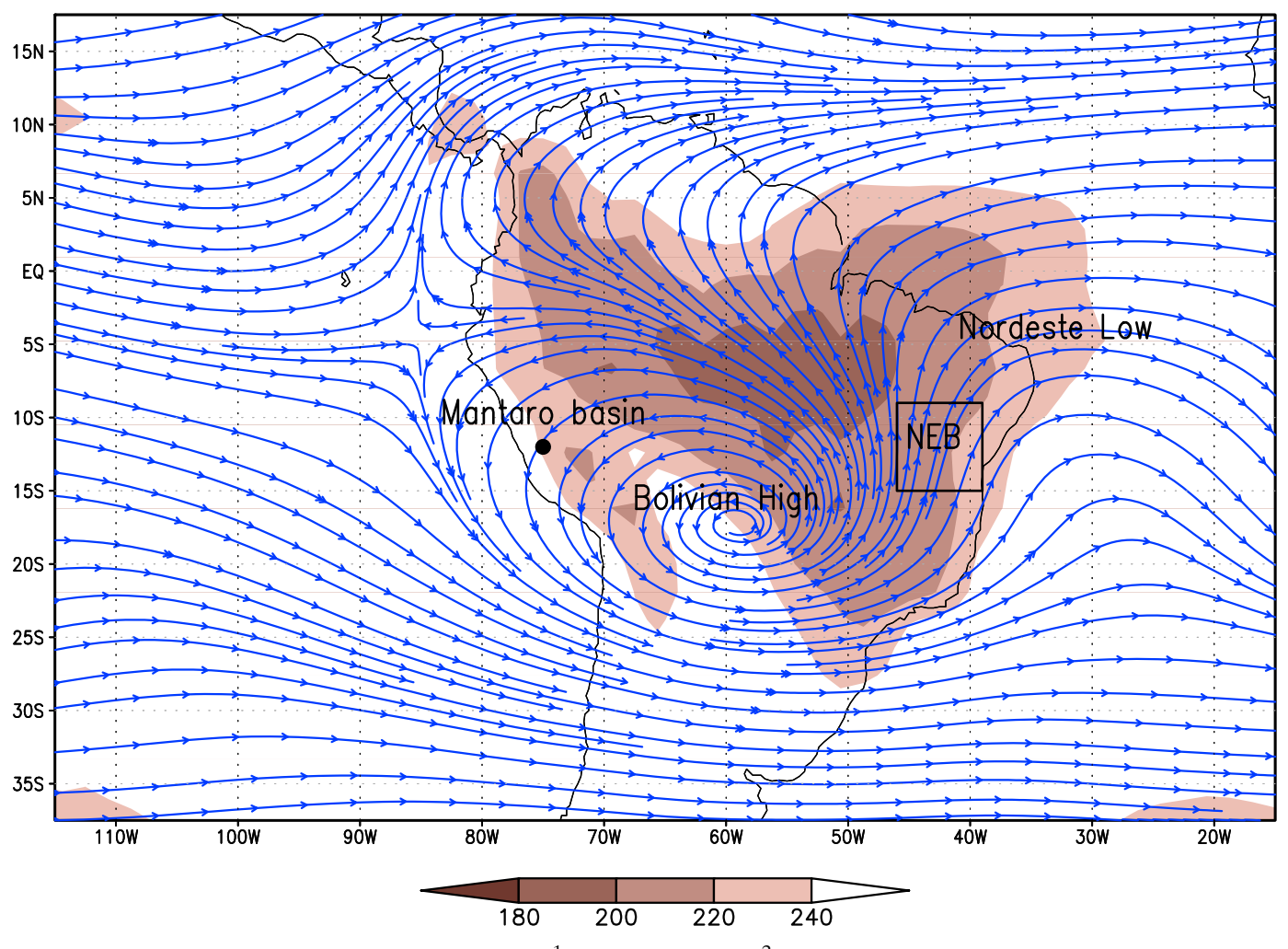

FIG. 2. Climatology of DJFM 200-hPa winds $\left(\mathrm{m} \mathrm{s}^{-1}\right)$ and OLR $\left(\mathrm{W} \mathrm{m}^{-2}\right)$ for the period 1971-2010 from NCEP-NCAR reanalyses.

strong diabatic heating over the Amazon basin by modeling studies (e.g., Silva Dias et al. 1983; De Maria 1985; Figueroa et al. 1995; Lenters and Cook 1997). However, the strength and positioning of this high pressure system is quite variable. The NL is an upperlevel cyclone located near the northeastern coast of Brazil. This vortex is associated with net subsidence, compensating the intense upward vertical motion during the rainy months over the Amazon region according to regional energy balance studies (Kousky and Gan 1981). The BH-NL system is highly seasonal and disappears during the austral winter once the upper-level westerly zonal flow over South America starts to strengthen in austral fall. The monsoon precipitation extends southeastward from the Amazon basin toward the western South Atlantic $\left(20^{\circ}-40^{\circ} \mathrm{S}, 50^{\circ}-20^{\circ} \mathrm{W}\right)$ as a band of convective activity known as the South Atlantic convergence zone (SACZ), formed by interactions with synoptic-scale wave trains emanating from the midlatitudes (Liebmann et al. 1999). The SACZ is active all year; however, its maximum intensity is observed during the austral summer (e.g., Kodama 1992; Figueroa et al. 1995; Barreiro et al. 2002; Carvalho et al. 2004).

The BH-NL system varies in strength on various time scales, controlled primarily by three different forcings: local, Pacific, and African forcing. The local forcing is related to latent heat release during convection in the Amazon basin, which determines the basic structure of the BH-NL system (Silva Dias et al. 1983). Rainfall in the central Andes aids in further strengthening and displacing the BH southward (Lenters and Cook 1997). Similarly, the SACZ releases much condensational heat to the upper troposphere, which further enhances and forms the basic shape of the BH-NL system. Latent heat released over the western Pacific Ocean can also modulate the strength of the BH-NL system (Gandu and Silva Dias 1998). This is no surprise given that it is well understood that the shape of the Walker circulation depends on the configuration of the convective core over the Pacific Ocean. In general, the BH-NL system weakens in response to suppressed convective activity over the western Pacific, leading to drier conditions in the central Andes and Amazon basin by displacing the Walker circulation westward (Chen et al. 1999). Since variations in convective activity over the western Pacific are intimately related to ENSO, this forcing can help explore the interannual variability of the $\mathrm{BH}-\mathrm{NL}$ system. Finally, convective activity over equatorial and subtropical Africa also has the ability to affect the strength of the BH-NL system. Equatorial convection 
TABLE 1. List of stations used in this study.

\begin{tabular}{|c|c|c|c|c|}
\hline Weather station & Lat (S) & Lon $(\mathrm{W})$ & Alt (m MSL) & Source \\
\hline Marcapomacocha & $11.40^{\circ}$ & $76.33^{\circ}$ & 4413 & SENAMHI \\
\hline Ingenio & $11.88^{\circ}$ & $75.26^{\circ}$ & 3450 & SENAMHI \\
\hline Acobamba & $12.84^{\circ}$ & $74.57^{\circ}$ & 3236 & SENAMHI \\
\hline Lircay & $12.98^{\circ}$ & $74.72^{\circ}$ & 3150 & SENAMHI \\
\hline Huancavelica & $12.78^{\circ}$ & $74.98^{\circ}$ & 3676 & ELECTROPERU \\
\hline Junin & $11.15^{\circ}$ & $75.99^{\circ}$ & 4120 & ELECTROPERU \\
\hline Kichuas & $12.47^{\circ}$ & $74.77^{\circ}$ & 2650 & ELECTROPERU \\
\hline Mejorada & $12.53^{\circ}$ & $74.86^{\circ}$ & 2820 & ELECTROPERU \\
\hline Pachacayo & $11.81^{\circ}$ & $75.72^{\circ}$ & 3550 & ELECTROPERU \\
\hline Palaco & $12.35^{\circ}$ & $75.30^{\circ}$ & 3650 & ELECTROPERU \\
\hline Pampas & $12.39^{\circ}$ & $74.87^{\circ}$ & 3260 & ELECTROPERU \\
\hline Tambo de Sol & $10.87^{\circ}$ & $76.12^{\circ}$ & 4100 & ELECTROPERU \\
\hline Telleria & $12.38^{\circ}$ & $75.12^{\circ}$ & 3050 & ELECTROPERU \\
\hline Huayao & $12.04^{\circ}$ & $75.32^{\circ}$ & 3308 & IGP \\
\hline
\end{tabular}

tends to enhance convergence over NEB at upper levels and therefore strengthens the $\mathrm{BH}-\mathrm{NL}$ system, while forcing from subtropical Africa weakens the BH-NL system through enhanced convergence over northern South America. When combined, however, the two forcings contribute positively to the formation of the BH-NL system (Lenters and Cook 1997; Chen et al. 1999; Cook et al. 2004).

Many studies document the relationship between ENSO and the interannual rainfall variability in the Mantaro basin, in the sense that below-normal rainfall tends to occur during the warm ENSO phase and abovenormal precipitation tends to occur during the ENSO cold phase (Silva et al. 2008; Lavado Casimiro et al. 2012), consistent with studies to the south over the broader Altiplano region (Vuille 1999; Vuille et al. 2000; Garreaud and Aceituno 2001; Garreaud et al. 2003; Vuille and Keimig 2004). The ENSO signal is highly significant in the Mantaro basin during the austral spring and early summer, and to a lesser extent also during winter (Instituto Geofísico del Perú 2005b; Lagos et al. 2008).

On shorter time scales (5-10 days), extratropical Rossby waves propagating equatorward from midlatitudes toward the tropics play an important role in modulating the characteristics of convective activity over the SACZ and the broader BH-NL system. The intensity and location of the SACZ, for example, is modulated by extratropical Rossby waves that propagate equatorward along the eastern coast of South America (e.g., Kousky 1979; Diaz and Aceituno 2003; Carvalho et al. 2004; De Souza and Ambrizzi 2006; Muza et al. 2009; Kodama et al. 2012). Ma et al. (2011) further documented that the SACZ activity is even modulated by midlatitude Rossby wave trains on interannual time scales. On the other hand, relatively little is known about the effects of equatorward extratropical Rossby wave propagation on the location and strength of the BH-NL system and precipitation in the central Andes on subseasonal time scales (e.g., Garreaud 1999; Hurley et al. 2015). Some studies, however, have documented that intraseasonal phenomena, such as the Madden-Julian oscillation (MJO), can modulate the location and strength of the BH-NL system (Alvarez et al. 2015). De Souza and Ambrizzi (2006), for example, documented how the MJO is able to weaken the $\mathrm{BH}-$ NL system, while enhancing convective activity over tropical Brazil. However, to our knowledge, no studies to date have linked this impact of the MJO on tropical convection or SACZ activity with the occurrence of extreme dry or wet spells in the Mantaro basin.

As will be shown below, our results indicate a significant link between extreme events in the Mantaro basin and a region of northeastern Brazil (see section 3b). To further analyze this relationship, we define a box over the area $\left(9^{\circ}-15^{\circ} \mathrm{S}, 39^{\circ}-46^{\circ} \mathrm{W}\right)$. Rainfall in this area has a well-defined annual cycle with a maximum from November to March. This region represents the driest part of Brazil with approximately $500 \mathrm{~mm}$ annual precipitation and large interannual variability. Kousky (1979), Kousky and Ferreira (1981), and Liebmann et al. (2011) documented that discrete precipitation events in NEB are mainly caused by northward-propagating midlatitude cold fronts, similar to the results documented recently for major snowfall events in the Andes of Peru by Hurley et al. (2015).

\section{Data and methodology}

To identify dry and wet spells in the Mantaro basin, we used daily rainfall data from 14 stations within the Mantaro basin during the austral summer (DJFM) from 
1965 to 2002 (Table 1). The data sources were the Peruvian National Service of Meteorology and Hydrology [Servicio Nacional de Meteorología e Hidrología del Perú (SENAMHI)], the Peruvian Geophysical Institute [Instituto Geofisico del Perú (IGP)], and ELECTROPERU (Fig. 1). The selected stations contain less than $10 \%$ of missing values in their DJFM time series. To identify the days of occurrence of dry and wet spells in northeastern Brazil, we used $1^{\circ} \times 1^{\circ}$ daily gridded rainfall data from the Liebmann and Allured (2005) dataset for the same period as in the Mantaro basin.

To characterize the large-scale circulation over South America associated with these extreme rainfall events in both regions, we used $2.5^{\circ} \times 2.5^{\circ} \mathrm{NCEP}-\mathrm{NCAR}$ reanalyses data (Kalnay et al. 1996) for the same period, focusing on wind $(850,500$, and $200 \mathrm{hPa})$, specific humidity ( 850 and $500 \mathrm{hPa}$ ), and outgoing longwave radiation (OLR) during austral summer. Furthermore, to identify the large-scale rainfall pattern associated with dry events in the MB, we used pentad CPC Merged Analysis of Precipitation (CMAP) rainfall data that have a resolution of $2.5^{\circ} \times 2.5^{\circ}$ for the period 1979-2002 (Xie and Arkin 1997). Finally, to study the relationship between extreme rainfall events and El Niño, we used the Niño-3.4 index from NOAA's Earth System Research Laboratory (ESRL; http://www.cpc.ncep.noaa. gov/data/indices/ersst3b.nino.mth.81-10.ascii). To assess the relative frequency of extreme rainfall events in the MB during each phase of ENSO and to test whether they are significantly different from one another, we used the test of difference of proportions (Spiegel and Stephens 1998).

Wet spells in both locations were defined as periods where the daily rainfall amount exceeds its 70 th percentile for at least three consecutive days. Dry spells were similarly defined for both regions as periods when the rainfall did not exceed its 30th percentile for at least five consecutive days. The threshold of five days was chosen because spectral analysis shows that rainfall and wind (at low levels) over northeastern Brazil can significantly change on time scales of 5 days and more (Carvalho et al. 2002).

To identify the days of occurrence of these events, we used daily rainfall data from 14 stations in the MB for the period 1965-2002. Over NEB, we defined a daily rainfall index from the average of daily gridded rainfall data within the region $9^{\circ}-15^{\circ} \mathrm{S}, 39^{\circ}-46^{\circ} \mathrm{W}$ for the same period.

To characterize the large-scale Pacific and African forcing of dry spells in the Mantaro basin, we analyzed the anomalous rainfall pattern using pentad gridded rainfall data from CMAP for the period 1979-2002 (Xie and Arkin 1997). Only pentads fully embedded within the dates of dry spell occurrence were used. Unfortunately, the same criterion could not be applied to characterize wet spells as most of them partially overlap with two consecutive pentads and therefore represent a noisy signal mixing wet and dry conditions.

Composite and superposed epoch analysis were applied to identify anomalous regional-scale circulation, deep convection, and rainfall associated with these events. Statistical significance was assessed using a Student's $t$ test (Wilks 2011).

\section{Results and discussion}

Circulation anomalies linked to episodes of dry and wet spells in the Mantaro basin and NEB during the austral summer are discussed and compared with results from previous studies.

\section{a. Mantaro basin}

In this study, we identified 58 dry and 43 wet spells in the Mantaro basin with an average duration of 7.24 and 3.54 days, respectively.

Figures 3 and 4 show the results from our composite analysis for dry and wet spells, respectively, including patterns of wind at 200,500 , and $850 \mathrm{hPa}$; specific humidity at 500 and $850 \mathrm{hPa}$; and OLR. Figure 3a shows that dry events in the Mantaro basin are characterized by a robust OLR dipole pattern of positive OLR anomalies over the study area whereas significant negative OLR anomalies exist over NEB. These anomalies are consistent with the station-based finding of drier conditions over the Peruvian central Andes, but also show that the dry conditions and reduced convective activity affect a larger region than just the Mantaro basin itself. More importantly, it indicates that these dry spells may be tied to larger-scale circulation anomalies, at the same time inducing enhanced convective activity over NEB, potentially tied to a change in the position of the SACZ toward the northeast. During wet spells (Fig. 4a) the OLR anomalies are essentially reversed, although the area of enhanced convective activity is significantly larger, affecting the entire central Andes region from Colombia to northern Argentina. Again, a conspicuous dipole with reduced OLR can be observed over eastern Brazil, extending over the SACZ region.

The OLR anomalies in both cases are clearly tied to large-scale upper-air zonal wind anomalies over the Peruvian Andes. Figure 3b shows that westerly wind anomalies prevail over the entire central Peruvian Andes at $200 \mathrm{hPa}$ during dry events in the MB. At the same time, positive geopotential height and southerly wind anomalies can be observed around the NL, associated with the enhanced convective activity over NEB. The anomalous cyclonic circulation with center around $15^{\circ} \mathrm{S}$, $50^{\circ} \mathrm{W}$ along with the anticyclonic anomalies in the 
a) $0.1 *$ OLR (W/m2) anom.

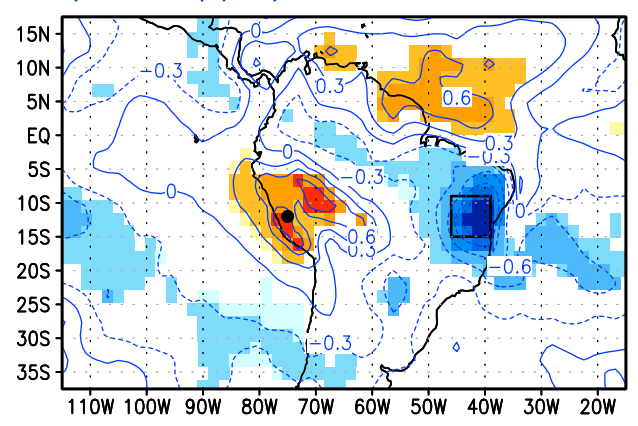

c) $500 \mathrm{hPa}$ Winds $(\mathrm{m} / \mathrm{s})$ \& Spec.hum. $(\mathrm{g} / \mathrm{kg})$ anom.

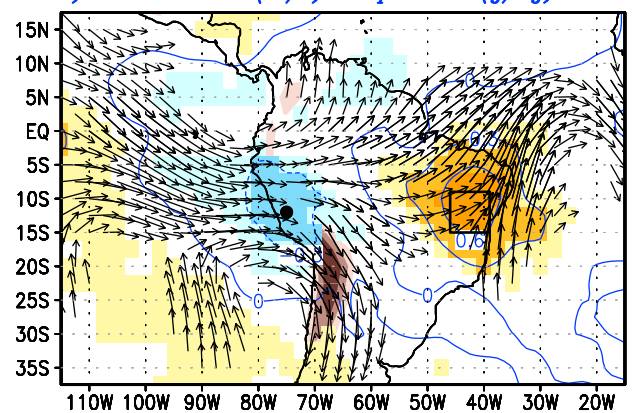

b) $200 \mathrm{hPa}$ Winds $(\mathrm{m} / \mathrm{s})$ \& $0.05 *$ Geop.h.(m) anom.
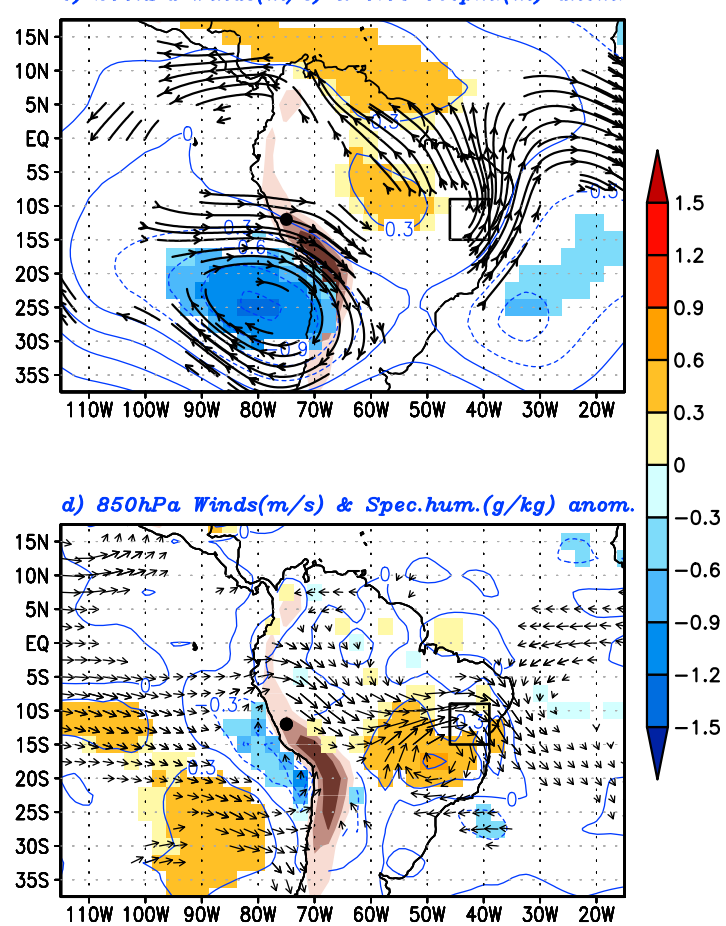

5

FIG. 3. Composite anomalies during dry events in MB for (a) OLR ( $\mathrm{W} \mathrm{m}^{-2}$ ), (b) 200-hPa geopotential height (m) and streamlines $\left(\mathrm{m} \mathrm{s}^{-1}\right)$, and (c) 500-hPa wind $\left(\mathrm{m} \mathrm{s}^{-1}\right)$ and specific humidity $\left(\mathrm{g} \mathrm{kg}^{-1}\right)$. (d) As in (c), but for $850 \mathrm{hPa}$. Only wind, streamlines, humidity, and OLR anomalies statistically significant at the $95 \%$ confidence level are shown. Analysis is based on data from 1965 to 2002. Confidence level is based on a two-sided Student's $t$ test. The 1000- and 3000-m topographic contours are indicated by brown shading. Note that OLR and 200-hPa geopotential height values are scaled by a factor of 0.1 and 0.05 , respectively.

tropical Atlantic and convergence of winds in the Atlantic are characteristic of an intensified SACZ (Carvalho et al. 2004). During wet spells the winds over the MB are essentially reversed (upper-level easterlies; Fig. 4b), while negative geopotential height anomalies and anomalous anticyclonic circulation with reduced convection prevail over NEB. Figure 5 corroborates all these observations through streamlines of winds at $200 \mathrm{hPa}$. For example, Fig. 5a shows that the weakening of the NL observed during dry spells in the MB coincides with an eastward displacement of its climatological position, while Fig. 5b illustrates that the strengthening of the NL over NEB during a wet spell in the MB is related to a shrinking and southwestern displacement from its climatological position. These circulation anomalies observed during dry and wet spells in the MB are consistent with a weakened and enhanced BH-NL system, respectively (Chen et al. 1999).

The westerly wind anomalies during dry periods are still apparent at $500 \mathrm{hPa}$ (Fig. 3c) and extend across
South America toward the southern tropical Atlantic. The OLR anomalies are mirrored in the 500-hPa specific humidity anomalies, which again highlight the dipole aspect between the MB and NEB (Figs. 3c, 4c). All results for the MB support previous analyses of atmospheric circulation anomalies related to dry and wet conditions in the Altiplano region farther south (e.g., Vuille 1999; Garreaud 1999; Garreaud et al. 2003; Vuille and Keimig 2004), suggesting that these same mechanisms and large-scale controls on moisture transport also operate farther north over the $\mathrm{MB}$ and are also applicable to the analysis of extreme events. Interestingly, however, there also appears to be a relationship between extreme events in the $\mathrm{MB}$ and the low-level circulation to the east (Figs. 3d, 4d). During dry spells in the $\mathrm{MB}$, northwesterly $850-\mathrm{hPa}$ wind anomalies prevail over the southwestern Amazon basin, east of the central Peruvian Andes. By contrast, during wet spells in the $\mathrm{MB}$, southeasterly $850-\mathrm{hPa}$ wind anomalies prevail over the southwestern Amazon basin. 
a) $0.1 * O L R(W / m 2)$ anom.

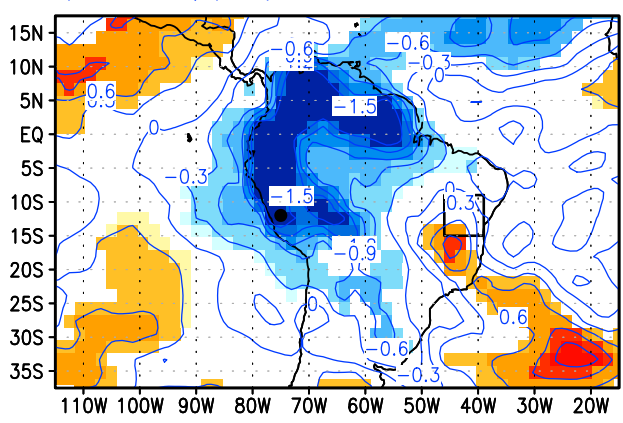

c) $500 \mathrm{hPa}$ Winds $(\mathrm{m} / \mathrm{s})$ \& Spec.hum. $(\mathrm{g} / \mathrm{kg})$ anom.

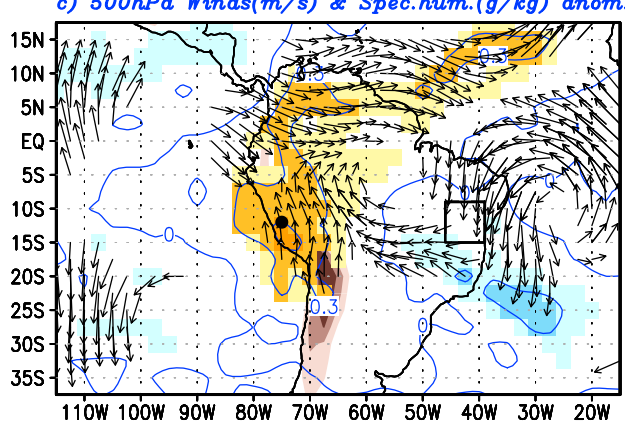

b) $200 \mathrm{hPa}$ Winds $(\mathrm{m} / \mathrm{s})$ \& $0.05^{*}$ Geop.h.(m) anom.

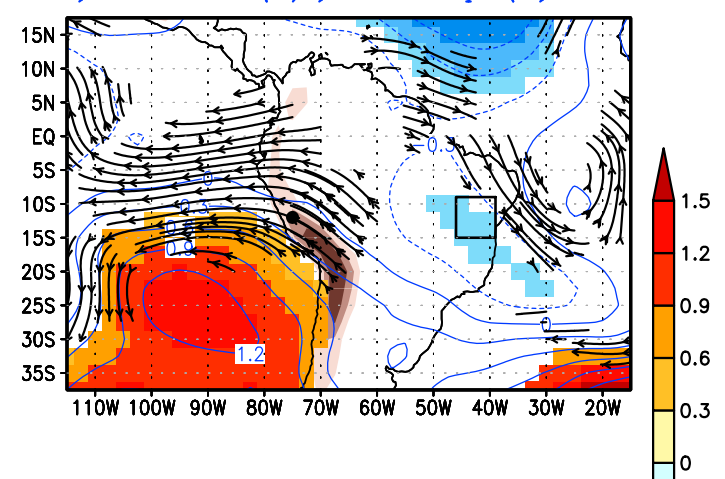

d) $850 \mathrm{hPa}$ Winds $(\mathrm{m} / \mathrm{s})$ \& Spec.hum. $(\mathrm{g} / \mathrm{kg})$ anom.

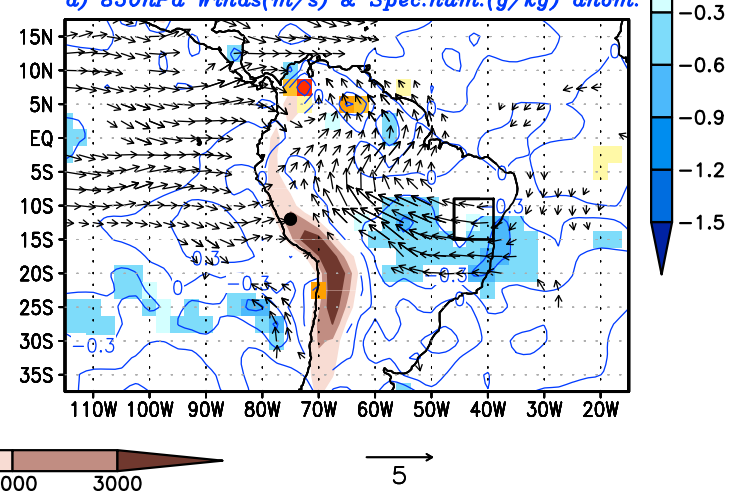

5

FIG. 4. As in Fig. 3, but for wet composite.

Figures $6 \mathrm{a}$ and $6 \mathrm{~b}$ show how specific humidity anomalies responsible for dry and wet extremes over the MB and $\mathrm{NEB}$, respectively, are linked through adjustments in the zonal and vertical circulation, where enhanced convection and upward motion in one region is balanced by enhanced subsidence in the other. This notion is consistent with the previous analysis linking these two regions through anomalous perturbations in the strength of the anticyclonic and cyclonic circulation systems over the MB and NEB, respectively.

200hPa EXTREME RAINFALL EVENTS - MANTARO BASIN(MB)-[DJFM:1965-2002]

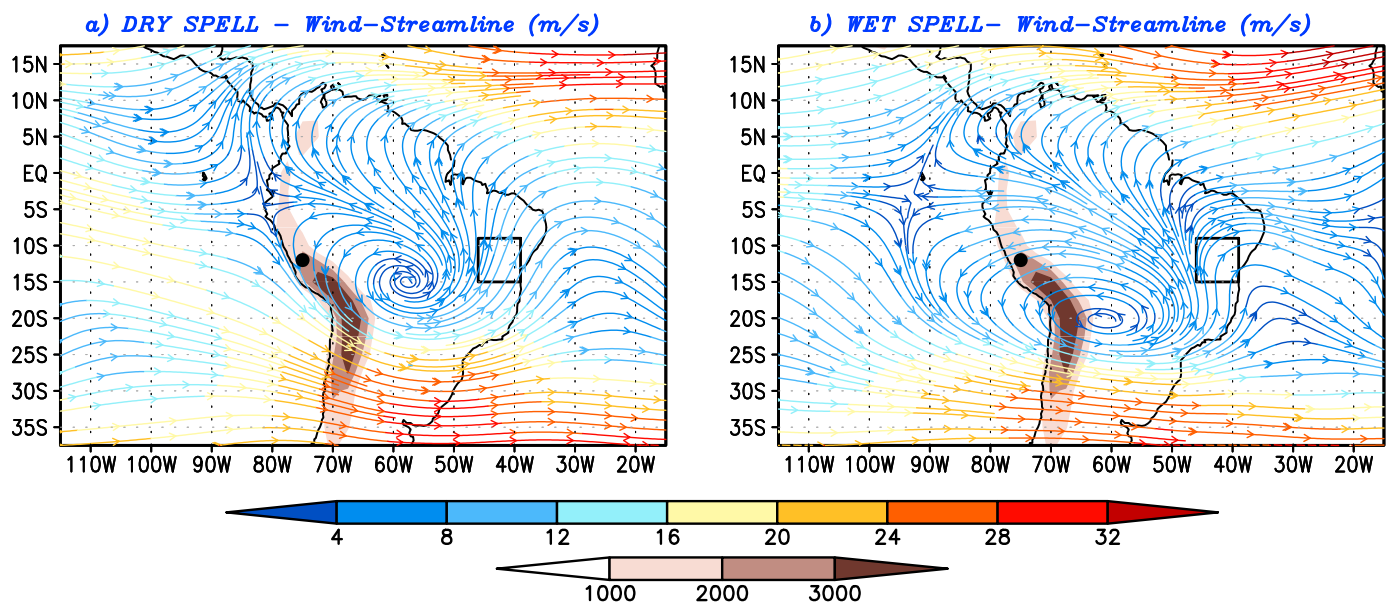

FIG. 5. Composite of 200-hPa streamlines $\left(\mathrm{m} \mathrm{s}^{-1}\right)$ during (a) dry and (b) wet spells in MB for the period 1965-2002 during austral summer (DJFM). 
CROSS SECTION (125) - EXTREME RAINFALL EVENTS - MANTARO BASIN(MB)-[DJFM:1965-2002]

a) DRY SPELL $(u,-w)[\mathrm{m} / \mathrm{s}, \mathrm{kPa} / \mathrm{s}]$ anom. \& Spec.hum. $[\mathrm{g} / \mathrm{kg}]$ anom.

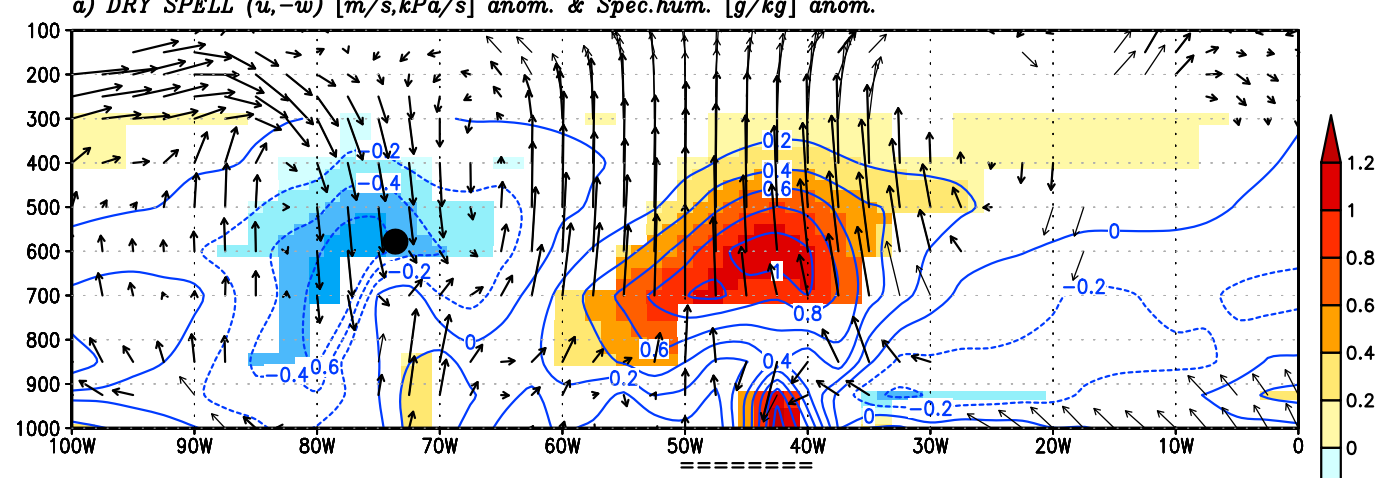

b) WET SPELL $(u,-w)[\mathrm{m} / \mathrm{s}, \mathrm{kPa} / \mathrm{s}]$ anom. \& Spec.hum. $[\mathrm{g} / \mathrm{kg}]$ anom.

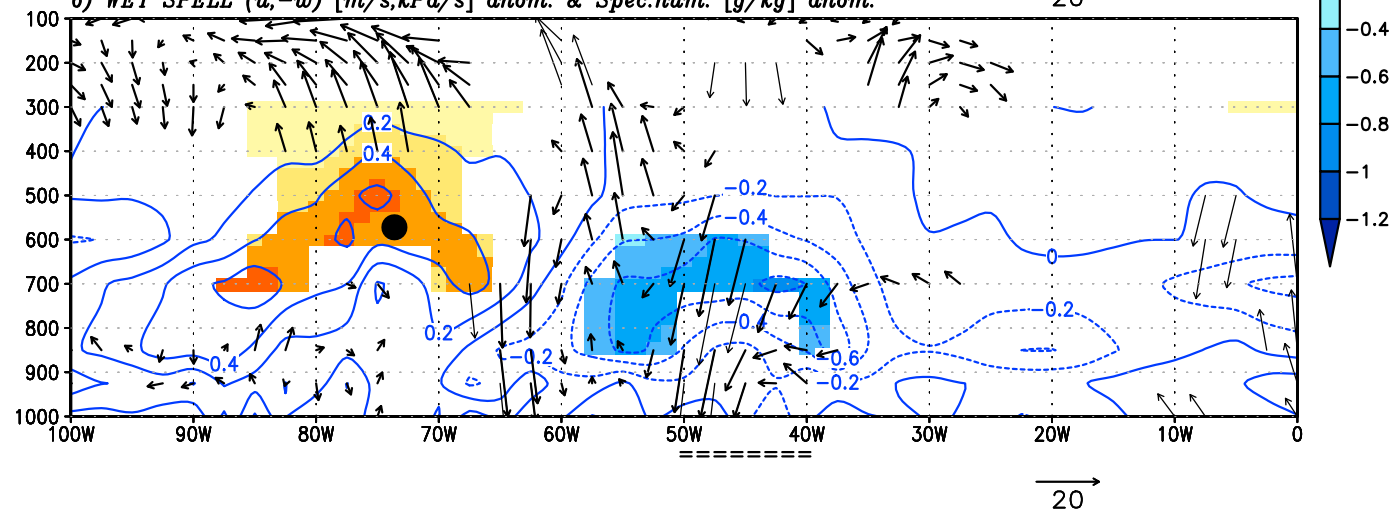

FIG. 6. Zonal wind $u\left(\mathrm{~m} \mathrm{~s}^{-1}\right)$, vertical motion $-\omega\left(\mathrm{kPa} \mathrm{s}^{-1}\right)$, and specific humidity $\left(\mathrm{g} \mathrm{kg}^{-1}\right)$ anomalies during (a) dry and (b) wet spells in $\mathrm{MB}$ at $12^{\circ} \mathrm{S}$. Color shading and vectors are statistically significant at the $95 \%$ confidence level. Black circle represents the location of $\mathrm{MB}$ while black double-dashed line along the $y$ axis represents the location of NEB.

Additional lagged composites of geopotential height anomalies at upper levels were created using a superposed epoch analysis approach to analyze the role of midlatitude Rossby waves in producing extreme rainfall events in the MB (Figs. 7, 8). Figure 7 shows geopotential height anomalies at $200 \mathrm{hPa}$ prior to, during, and following dry spells in the MB (days $-3,-2,-1$, $0,+1$, and +2$)$. A quasi-permanent anticyclone is located over the southern tip of South America, extending northward into the subtropics. Along its northwestern edge a cyclonic anomaly is established on day 0 off the coast of northern Chile, indicative of the weakening of the $\mathrm{BH}$. The cyclonic anomaly (weakened $\mathrm{BH}$ ) continues to deepen on day +1 and +2 , indicative of the persistent character of the dry anomaly over the MB, following the peak of the event. During wet events (Fig. 8), on the other hand, a cyclonic anomaly over southern South America slowly dissipates while propagating toward the northeast over days -3 to -1 . On its western side, an upper-level anticyclone has established by day 0 off the Chilean coast, strengthening upper-level easterly winds on its northern flank and thereby setting the stage for the wet event over the MB. Hence, these results suggest that Rossby wave propagation may indeed facilitate oscillations in the $\mathrm{BH}-\mathrm{NL}$ system strength and thus contribute to generation of wet and dry spells in the MB. This is consistent with results by Garreaud (1999), who also identified the propagation of midlatitude Rossby wave trains as a major driver for rainfall variability on the Altiplano on intraseasonal time scales.

The tropical rainfall composite (Fig. 9) using CMAP pentads confirms that dry periods in the MB are indeed associated with negative rainfall anomalies over most parts of the central Andes, whereas anomalies of the opposite sign are observed over NEB. However, additional tropical signatures are evident, highlighting the large-scale teleconnections of these dry events. In the Pacific Ocean, strong negative rainfall anomalies are recorded over the western part of the basin whereas the precipitation dipole stretching from northwest to southeast over the South Pacific indicates an 
200 hPa Geop. h.(m) anom. [NCEP/NCAR] DRY SPELL - MANTARO BASIN(MB)-[DJFM:1965-2002]

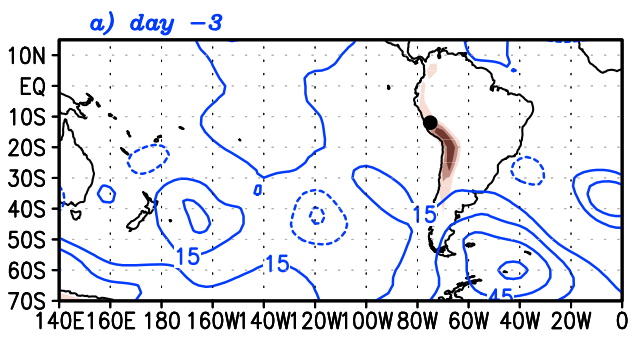

b) day -2

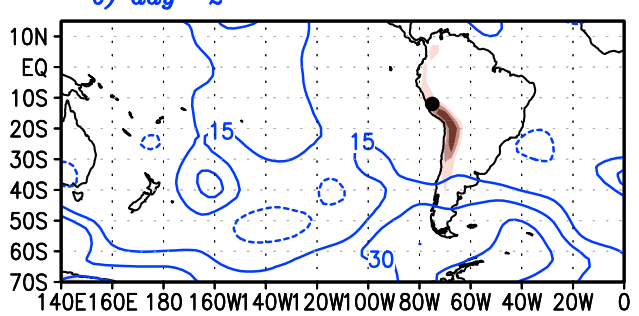

c) day -1

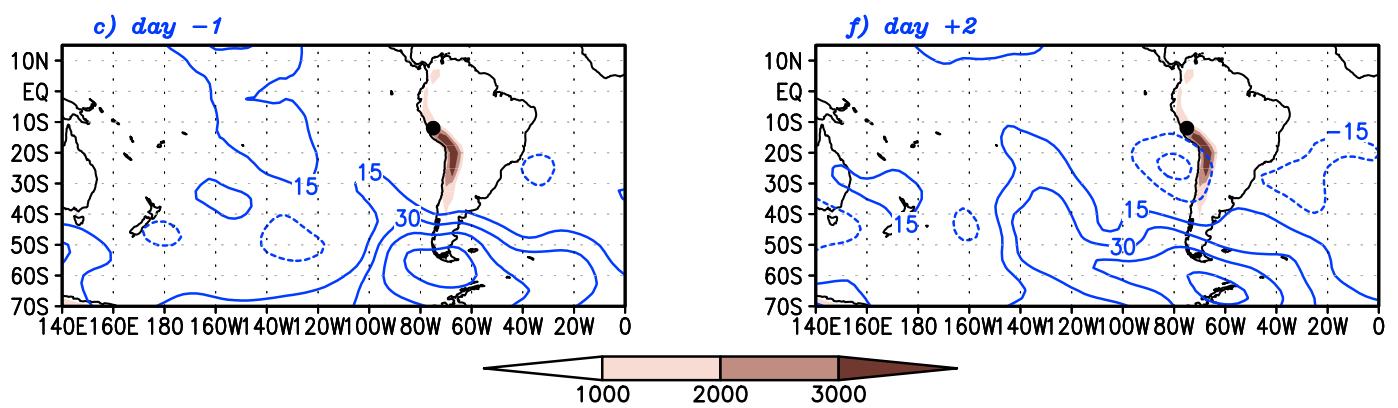

FIG. 7. Superposed epoch analysis for geopotential height $(\mathrm{m}$; contours with an interval of $15 \mathrm{~m}$ and with negative contours dashed) anomalies at $200 \mathrm{hPa}$ during dry spells in MB. Analysis based on data during austral summer (DJFM) from 1965 to 2002. The 1000-, 2000-, and 3000-m topography isolines are indicated by brown shading. enhancement and eastward displacement of the South Pacific convergence zone (SPCZ). The reduced convective activity observed over the western Pacific Ocean is in good agreement with the significant positive relationship between the number of dry events per year and the Niño-3.4 index during austral summer $(r=$ $0.474, p<0.05$, not shown).

Consequently, El Niño years appear to favor the occurrence of dry episodes in the MB. The large-scale precipitation anomalies seen in the global tropics during dry events in the $\mathrm{MB}$ are consistent with previous studies, as both the African and the Pacific configurations are known to induce a weakening of the $\mathrm{BH}-\mathrm{NL}$ system (e.g., Chen et al. 1999; Hagos and Cook 2005). A simple stratification of the frequency of occurrence of dry spells per year in the MB into each phase of ENSO (Table 2) shows that such events are significantly more likely to occur during El Niño (2.20 events per year) as compared to La Niña events ( 0.76 events per year). The
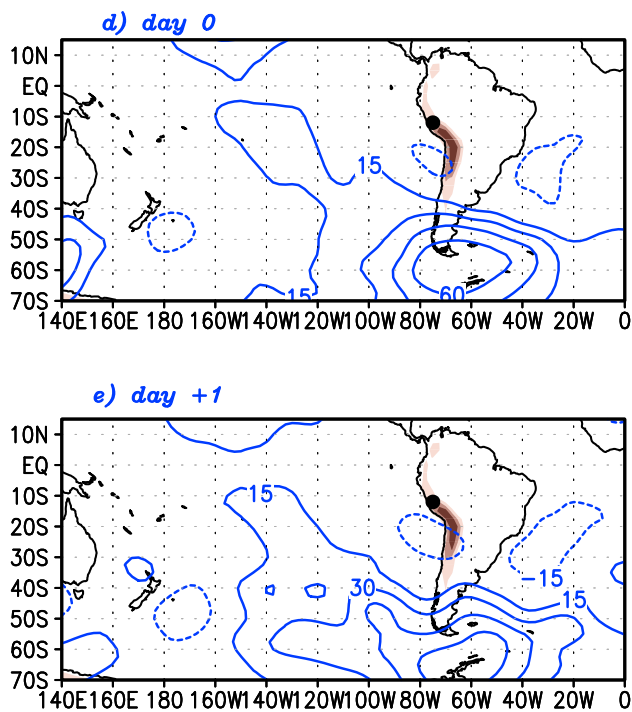

frequency of occurrence of wet spells in the MB on the other hand, while more than twice as likely during La Niña events, is statistically not distinguishable between the two phases of ENSO.

Finally, it is noteworthy to point out that rainfall in the Mantaro basin does not exhibit a simple linear relationship with zonal wind at $200 \mathrm{hPa}$ (Fig. 10), as documented for the Altiplano region farther south (e.g., Garreaud et al. 2003). Clearly, rainfall over the Mantaro basin can be generated during periods of both easterly and westerly wind anomalies at upper levels. Extreme wet periods $\left(>8 \mathrm{~mm} \mathrm{day}^{-1}, \sim 90\right.$ th percentile), however, are almost exclusively tied to easterly wind anomalies at the upper level (sector II), whereas episodes of strong westerly winds suppress wet spells (sector III). More importantly, however, this analysis also shows that many periods of very strong upper-level easterlies exist, where no strong rainfall extremes occur (sector I). In other words, these results show that 

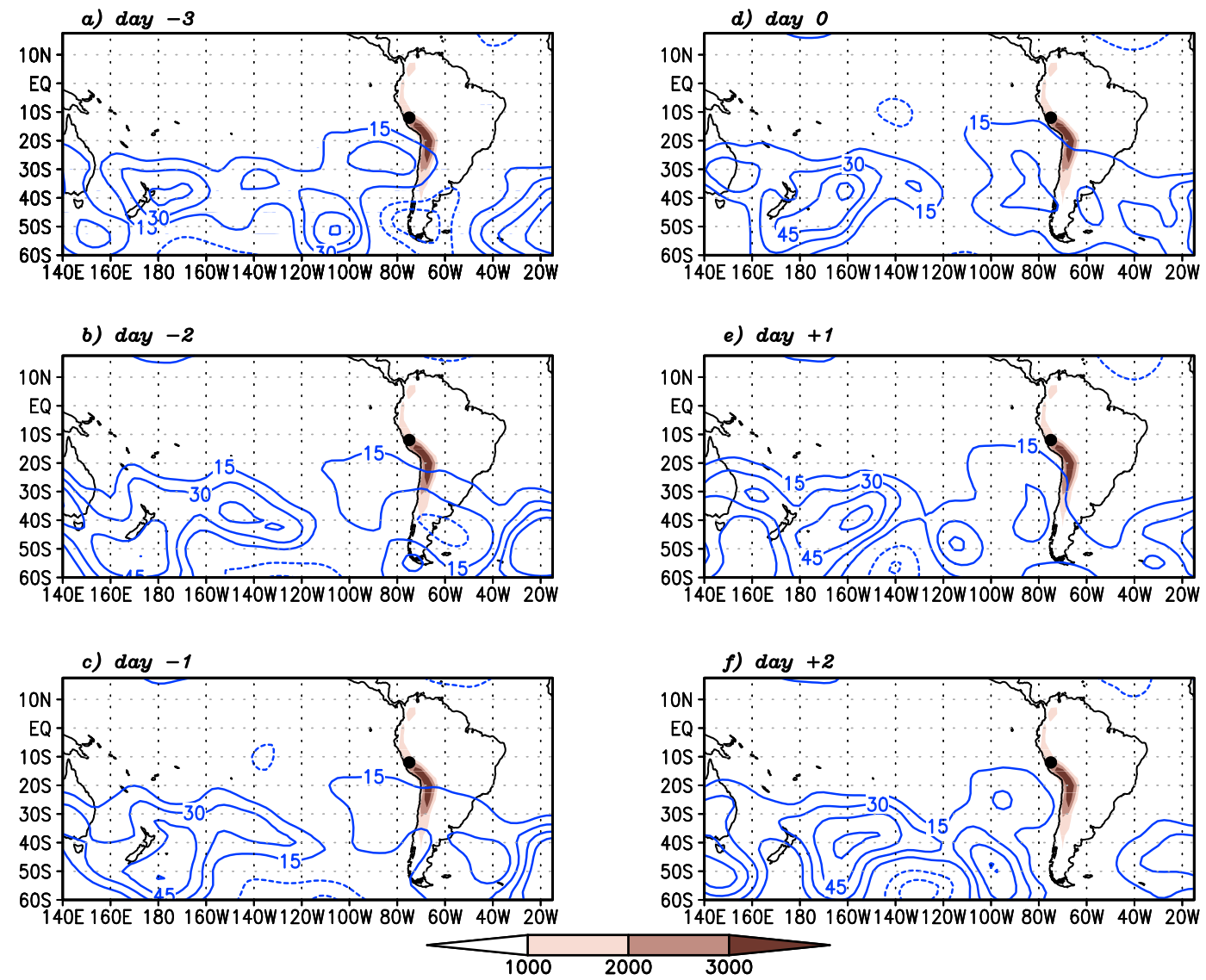

FIG. 8. As in Fig. 7, but for wet events.

upper-air easterlies may be a required, but not a sufficient forcing, to generate wet spells in the Mantaro basin.

An additional composite analysis contrasts weak $\left(\leq 4 \mathrm{~mm}_{\text {day }}{ }^{-1}, \sim 60\right.$ th percentile) and heavy $\left(\geq 8 \mathrm{~mm}_{\text {day }}{ }^{-1}\right.$, $\sim 90$ th percentile) rainfall events in the Mantaro basin (Fig. 11). Both types of rainfall events are characterized by significant upper-air easterly wind anomalies aloft, extending from the Amazon basin across the Andes toward the Pacific Ocean (Figs. 11a,d). However, at low levels, the circulation anomalies are quite different during a weak and heavy rainfall event. For example, Fig. 11b shows that heavy events are associated with significant low-level southeasterly wind anomalies over the central Amazon basin, while weak events are characterized by reduced specific humidity over the southern Amazon basin and anomalous northwesterly flow to the east of the Andes, inhibiting moisture flux toward the eastern Andean slopes (Fig. 11e). The anomalous OLR field suggests that precipitation anomalies during heavy rainfall events are much more widespread and extend from Peru to Ecuador and Colombia (Fig. 11c). In summary, this suggests that while favorable upper-air circulation is a necessary prerequisite for extreme wet conditions in the $\mathrm{MB}$, the low-level circulation is also important, as it allows for sufficient moisture influx to the region under conditions of prevailing low-level southeasterly winds. The exact local-scale forcing of orographic precipitation over the

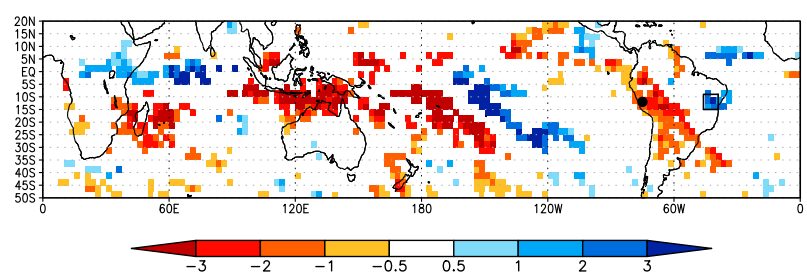

FIG. 9. DJFM precipitation $\left(\mathrm{mm} \mathrm{day}^{-1}\right)$ anomalies during dry events in $\mathrm{MB}$ between $50^{\circ} \mathrm{S}$ and $20^{\circ} \mathrm{N}$. Color shading indicates regions where anomalies are statistically significant at the $90 \%$ confidence level based on a Student's $t$ test. Period is from 1979 to 2002 . Precipitation data from CMAP. 
TABLE 2. Frequency of extreme rainfall events in the MB per year for each phase of ENSO during austral summer for the period 1965-2002. Boldface numbers indicate that the differences of the means are statistically significant at the $95 \%$ confidence level.

\begin{tabular}{lcc}
\hline \hline & $\begin{array}{c}\text { El Niño (events } \\
\text { per year) }\end{array}$ & $\begin{array}{c}\text { La Niña (events } \\
\text { per year) }\end{array}$ \\
\hline MB dry spell & $\mathbf{2 . 2 0}$ & $\mathbf{0 . 7 6}$ \\
MB wet spell & 0.60 & 1.35 \\
\hline
\end{tabular}

MB is beyond the scope of this study, but as pointed out by Garreaud (1999), it likely involves downward entrainment of the easterly momentum at all tropospheric levels over the eastern Andean ridge, thereby enhancing near-surface moisture influx from the eastern lowlands [see also Roe (2005)].

\section{b. Northeastern Brazil}

Given the apparent relationship between wet-dry periods in the Mantaro basin and phases of opposite precipitation characteristics over NEB, we next turn our attention to extreme rainfall events over NEB. We identified 107 dry and 103 wet spells in NEB over this same time interval with an average duration of 7.7 and 8.6 days, respectively. Overall $72.41 \%$ of the dry periods in MB coincide with wet events in NEB (which amounts to $34.93 \%$ of all wet events in NEB), whereas only $37.20 \%$ of wet spells in the MB coincide with dry events in NEB (which equals $14.95 \%$ of all dry events in NEB; Table 3).

Figures 12a and 13a show large-scale OLR anomalies during dry and wet spells over NEB. These OLR anomalies form a dipole pattern that reflects the northeast-southwest displacement of the SACZ over NEB and southeastern Brazil, respectively (e.g., Jones and Carvalho 2002; Carvalho et al. 2004), modulated by midlatitude wave trains, which are moving toward lower latitudes (Liebmann et al. 2011). There is, however, no statistically significant anomaly in OLR over the Mantaro basin during either type of extreme events in NEB. At upper levels, northerly wind anomalies and negative geopotential height anomalies are dominant over NEB during dry spells, associated with a strengthening of the NL. During wet extremes, on the other hand, southerly wind anomalies and positive geopotential height anomalies associated with a strengthened NL characterize the circulation over NEB. These circulation anomalies, however, do not extend to the Peruvian Andes, but instead are linked to circulation anomalies to the south, associated with the displaced SACZ (Figs. 12b, 13b). The OLR results are mirrored in the analysis of the mid- and lower-tropospheric humidity (Figs. 12c,d and $13 \mathrm{c}, \mathrm{d})$, which shows the same northeast-southwest

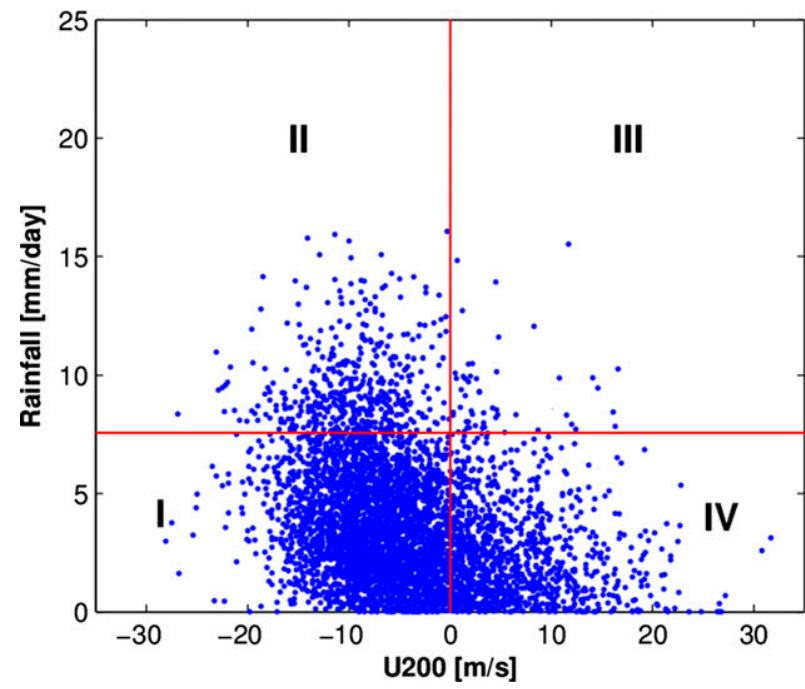

FIG. 10. Relationship between 200-hPa zonal wind $\left(\mathrm{m} \mathrm{s}^{-1}\right)$ located at $12^{\circ} \mathrm{S}, 75^{\circ} \mathrm{W}$ and rainfall $\left(\mathrm{mm}^{-1 a y}{ }^{-1}\right)$ in $\mathrm{MB}$. Analysis based on daily data from 1965 to 2002 .

dipole caused by the SACZ displacement. In summary, these results show that extreme events in NEB are clearly tied to SACZ displacements, but that the link to the Peruvian Andes is weak. Only a small fraction of extreme events in NEB coincides with extreme events of the opposite phase in the MB.

\section{Summary and conclusions}

Dry spells in the Mantaro basin during austral summer have an average duration of 7.24 days and are associated with a weakening of the $\mathrm{BH}-\mathrm{NL}$ system, resulting in robust patterns of westerly wind anomalies and significant positive OLR anomalies over the central Peruvian Andes. Wet spells, on the other hand, on average last 3.54 days and are characterized by a strengthened $\mathrm{BH}-$ NL system, easterly upper-air wind anomalies, and reduced OLR. The upper-air circulation anomalies associated with these events extend across tropical South America and lead to significantly enhanced convection over NEB during periods of dry extremes in the Mantaro basin, while convection over NEB is weakened during wet extremes in the MB. This precipitation dipole between the Peruvian Andes and NEB is the result of the dynamical link between $\mathrm{BH}$ and $\mathrm{NL}$, which weakens and strengthens seasonally in response to convective forcing over the Amazon basin, tropical Africa, and the western Pacific, but also appears sensitive to extratropical Rossby wave forcing on intraseasonal time scales. Precipitation extremes over NEB in particular are strongly affected by SACZ displacements, which in turn respond to the northward 
a) $200 \mathrm{hPa}(u ; v)[\mathrm{m} / \mathrm{s}]$ anom.

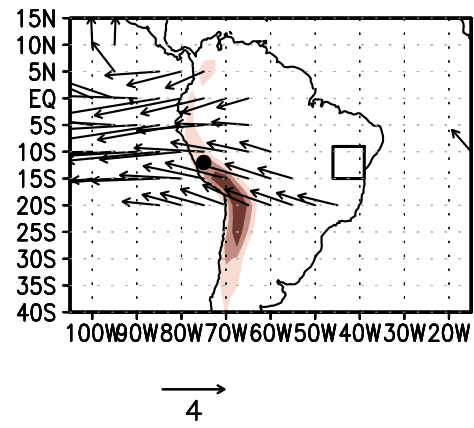

d) $200 \mathrm{hPa}(u ; v)[\mathrm{m} / \mathrm{s}]$ anom.

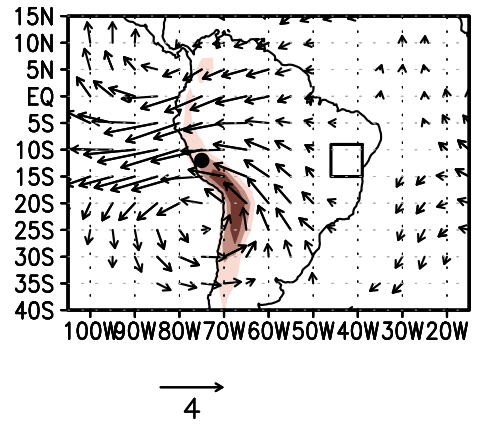

Heavy rainfall $>8 \mathrm{~mm} /$ day

b) $850 \mathrm{hPa}(u ; v)[\mathrm{m} / \mathrm{s}] \& q[\mathrm{~g} / \mathrm{kg}]$ anom.

c) $0.1 * O L R[W / m 2]$ anom.
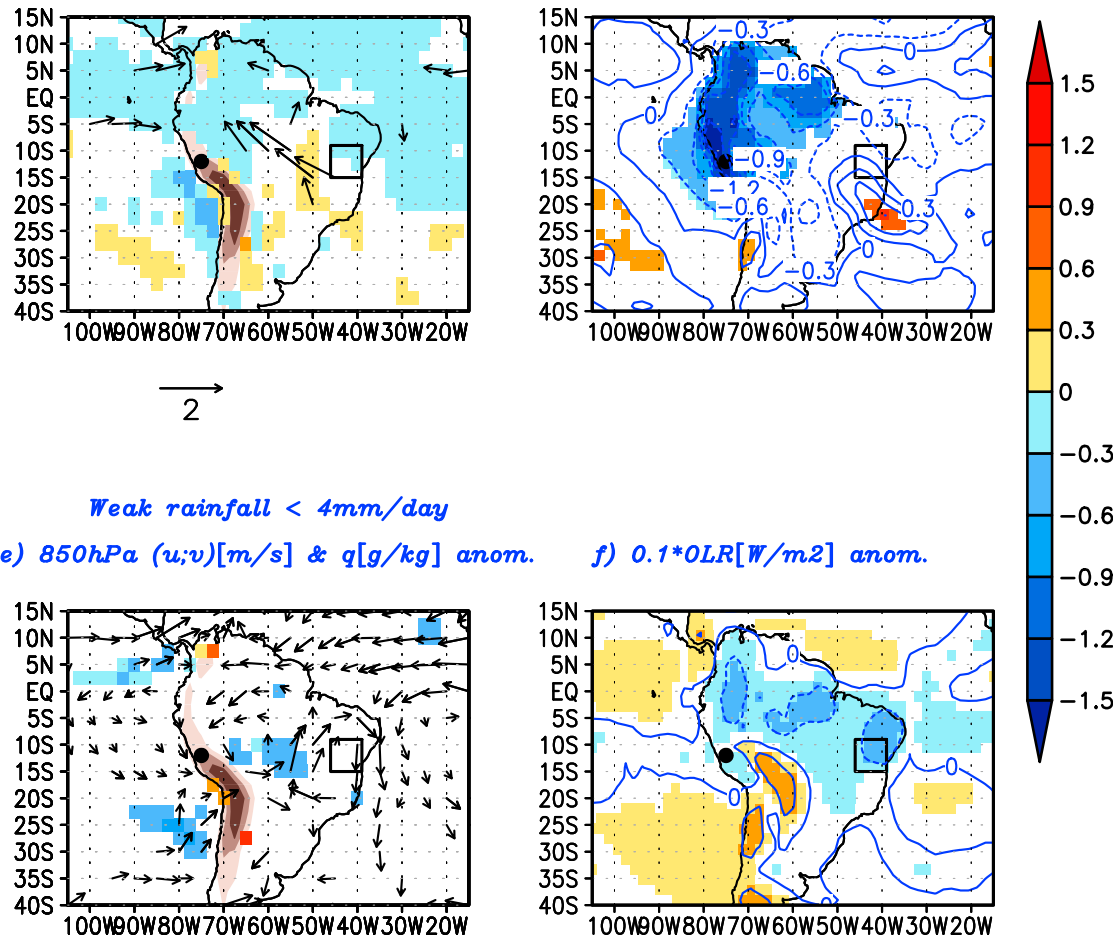

100k90W80W70W60W50W40W30W20W

f) $0.1 * O L R[W / m 2]$ anom.

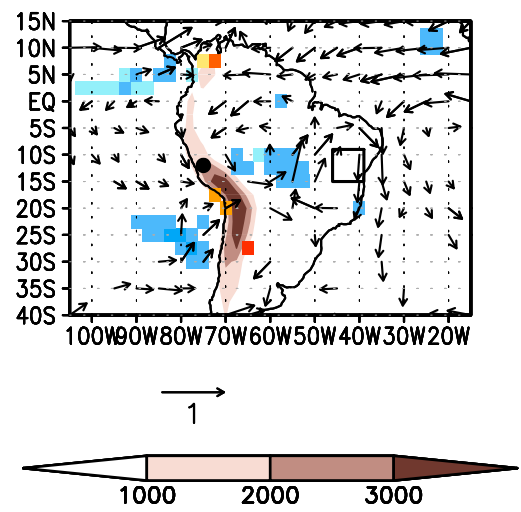

100W90W80W70W60W50W40W30W20W

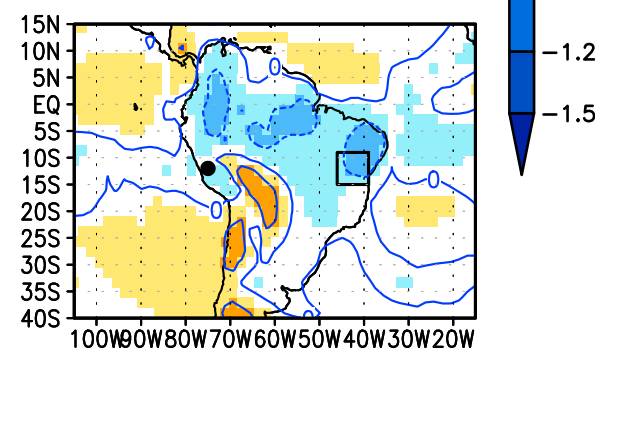

1.5 2 0.9 0.6 3

Weak rainfall < $4 \mathrm{~mm} /$ day

e) $850 \mathrm{hPa}(u ; v)[\mathrm{m} / \mathrm{s}] \& q[\mathrm{~g} / \mathrm{kg}]$ anom. 3 FIG. 11. Comparison between (top) heavy and (bottom) weak rainfall events in MB for the period 1965-2002 during austral summer
(DJFM) for anomalies of (a),(d) wind at $200 \mathrm{hPa}\left(\mathrm{m} \mathrm{s}^{-1}\right)$; (b),(e) wind $\left(\mathrm{m} \mathrm{s}^{-1}\right)$ and specific humidity $\left(\mathrm{g} \mathrm{kg}^{-1}\right)$ at $850 \mathrm{hPa}$; and (c),(f) OLR $\left(\mathrm{W} \mathrm{m}^{-2}\right)$. Only wind, specific humidity, and OLR anomalies statistically significant at the $95 \%$ confidence level are shown. Confidence level based on a two-sided Student's $t$ test. The 1000-, 2000-, and 3000-m topography isolines are indicated by brown shading.

propagation of midlatitude wave trains along the eastern coast of South America. The positioning of the BH is equally affected by northward Rossby wave propagation, thereby modulating upper-level easterlies and the generation of precipitation extremes in the MB.

While the results for the MB are consistent with our previous understanding of the dynamics and controls on moisture transport to the central Andes region, this study also found new links between the strength of MB precipitation and variations in the low-level circulation to the east of the Andes, which need to be explored further.

Our results suggest that upper-level easterly wind anomalies are a required, but insufficient forcing to create wet spells in the $\mathrm{MB}$, as many periods of sustained strong upper-level easterly winds lead to little or no precipitation at all. The low-level circulation to the east of the Andes appears to play an additional important role, with southeasterly winds providing an additional forcing. Nonetheless the explanatory power of upperand lower-level wind fields alone is insufficient to explain the large scatter in precipitation intensity seen in

TABLE 3. Percentage of extreme rainfall events occurring jointly in the $\mathrm{MB}$ and NEB. Boldface numbers represent the percentage of extreme rainfall events in $\mathrm{MB}$ and NEB relative to all events in $\mathrm{MB}$ while italic numbers represent the percentage of extreme rainfall events in MB and NEB relative to all events in NEB.

\begin{tabular}{lcc}
\hline \hline & NEB dry spell & NEB wet spell \\
\hline MB dry spell & $\mathbf{1 5 . 5 1} \%$ & $\mathbf{7 2 . 4 1} \%$ \\
& $8.41 \%$ & $34.93 \%$ \\
MB wet spell & $\mathbf{3 7 . 2 0} \%$ & $\mathbf{3 0 . 2 3} \%$ \\
& $14.95 \%$ & $7.83 \%$ \\
\hline
\end{tabular}


a) $0.1 * \operatorname{OLR}(W / m 2)$ anom.

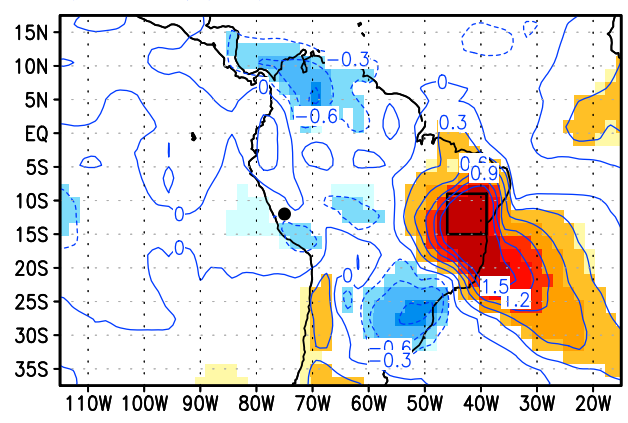

c) $500 \mathrm{hPa}$ Wind $(\mathrm{m} / \mathrm{s})$ \& Spec. hum. $(\mathrm{g} / \mathrm{kg})$ anom.

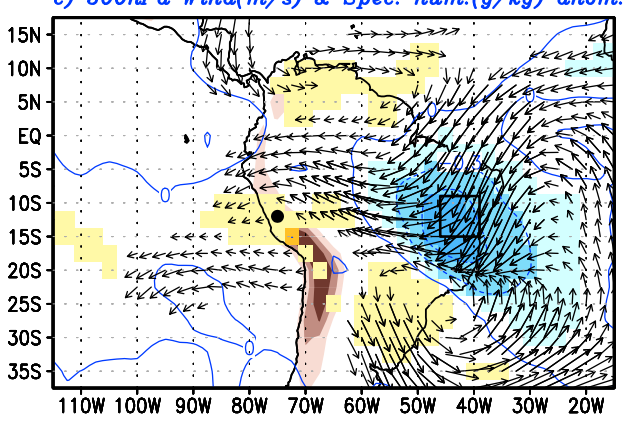

b) $200 h P a$ Wind $(m / s)$ \& 0.05*Geop. h. $(m)$ anom.

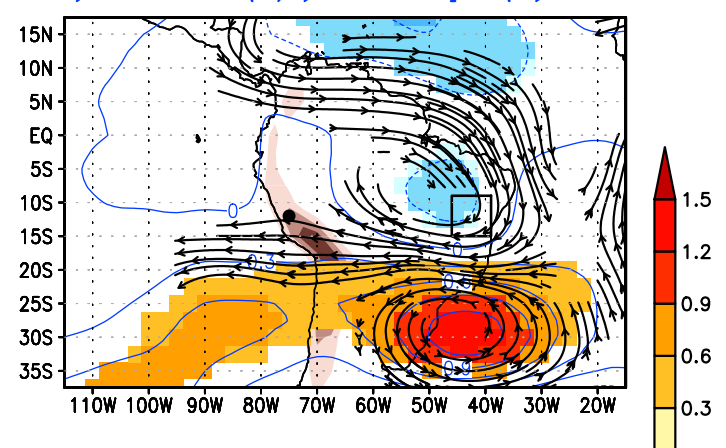

d) $850 \mathrm{hPa}$ Wind $(\mathrm{m} / \mathrm{s})$ \& Spec. hum. $(\mathrm{g} / \mathrm{kg})$ anom.

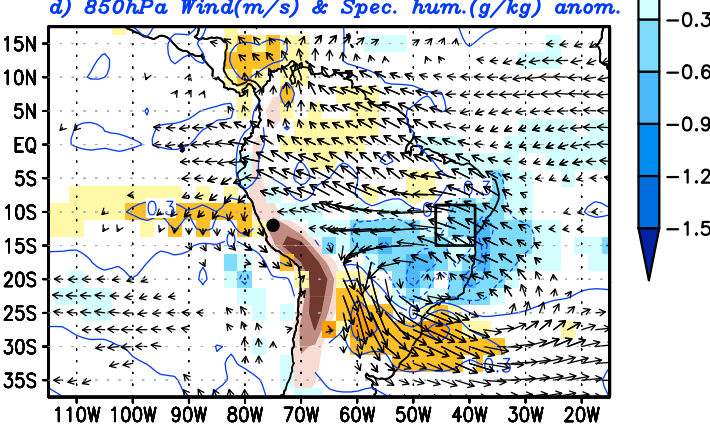

5

FIG. 12. Composite anomalies during dry events in NEB of (a) OLR $\left(\mathrm{W} \mathrm{m}^{-2}\right)$, (b) 200-hPa streamlines ( $\left.\mathrm{m} \mathrm{s}^{-1}\right)$ and geopotential height $(\mathrm{m})$, (c) 500-hPa wind $\left(\mathrm{m} \mathrm{s}^{-1}\right)$ and specific humidity $\left(\mathrm{g} \mathrm{kg}^{-1}\right)$, and (d) $850-\mathrm{hPa}$ wind $\left(\mathrm{m} \mathrm{s}^{-1}\right)$ and specific humidity $\left(\mathrm{g} \mathrm{kg}^{-1}\right)$. Only wind, specific humidity, and OLR anomalies statistically significant at the $95 \%$ confidence level are shown. Analysis based on data from 1965 to 2002. Confidence level based on a two-sided Student's $t$ test. The 1000-, 2000-, and 3000-m topography isolines are indicated by brown shading. Note that OLR and 200 -hPa geopotential height values are scaled by a factor of 0.1 and 0.05 , respectively.

the MB. Additional processes related to moisture transport to the east of the Andes need to be explored in greater detail to identify what additional physical processes influence the occurrence of wet spells over the Mantaro basin.

While the large-scale circulation anomalies (BH-NL system) that affect precipitation extremes in the $\mathrm{MB}$ region are also of relevance to NEB, the opposite is not the case, at least not to the same extent. Extreme events in NEB are much more strongly affected by northeastsouthwest displacements of the SACZ, a mechanism that does not provide a sufficient forcing to generate precipitation extremes in the MB. The MB-NEB dipole in precipitation extremes is therefore not a two-way street. While circulation anomalies that affect precipitation extremes in the MB in general also affect the precipitation characteristics in NEB, the opposite is not the case.

The ENSO phenomenon has a negative impact on rainfall in the Mantaro basin and appears to favor the occurrence of dry extremes. This is consistent with the observed suppression of convective activity over the western Pacific Ocean and the strengthening or eastward displacement of the SPCZ during dry episodes. However, factors other than ENSO apparently also favor the occurrence and frequency of dry events in the MB. For example, it has been suggested previously that a weakened $\mathrm{BH}-\mathrm{NL}$ system might rather be attributed to the negative phase of subtropical African forcing (e.g., Chen et al. 1999; Cook et al. 2004). By contrast, wet spell occurrence in the MB has a weak and insignificant relationship with ENSO.

Acknowledgments. The authors thank the U.S. State Department (award S-LMAQM-11-GR-086 under the ACCION umbrella to M.V.), Dr. Liebmann for providing the gridded daily rainfall data from Brazil, the National Peruvian Weather Service (SENAMHI), and ELECTROPERU and Electro-Andes for providing the station data to develop this research. NCEP-NCAR 
a) $0.1 * O L R(W / m 2)$ anom.

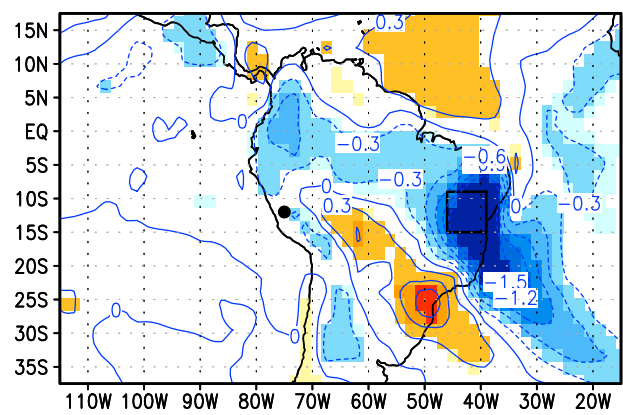

c) $500 \mathrm{hPa}$ Wind $(\mathrm{m} / \mathrm{s})$ \& Spec.hum. $(\mathrm{g} / \mathrm{kg})$ anom.

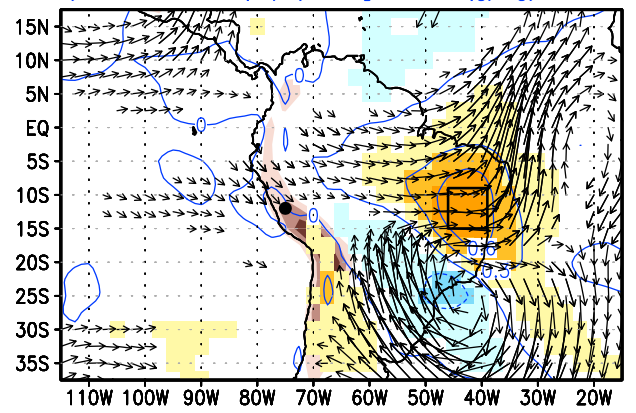

b) $200 \mathrm{hPa} W$ ind $(\mathrm{m} / \mathrm{s})$ \& $0.05^{*}$ Geop.h.(m) anom.

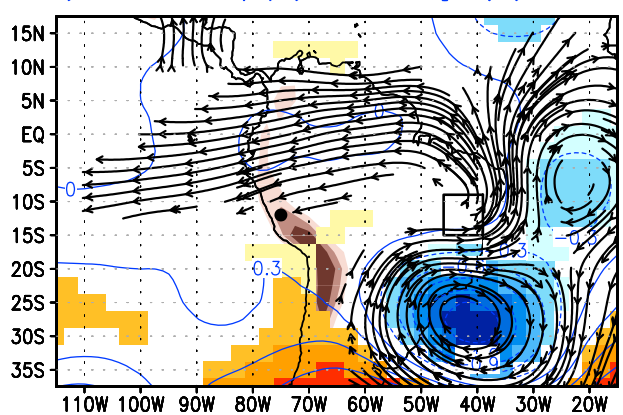

d) $850 \mathrm{hPa}$ Wind $(\mathrm{m} / \mathrm{s})$ \& Spec.hum. $(\mathrm{g} / \mathrm{kg})$ anom.

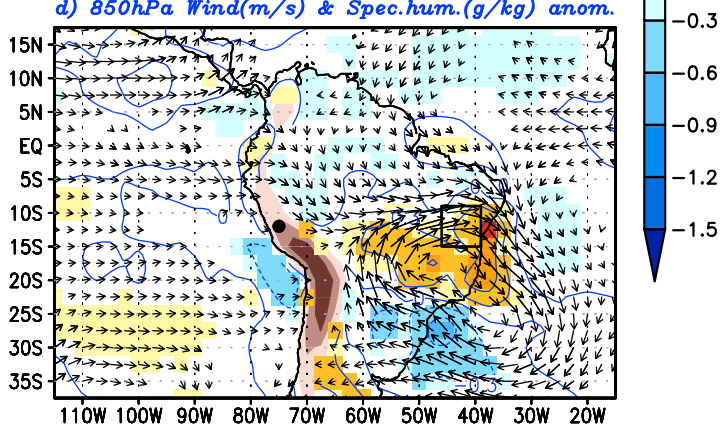

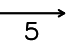
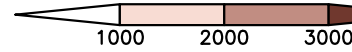

5

FIG. 13. As in Fig. 12, but for wet composite.

reanalyses data were retrieved from the NOAA Earth System Research Laboratory (ESRL). We are very grateful to R. Zubieta for his help with preparing the map for Fig. 1 and to two reviewers who provided us with extremely valuable and inspiring comments, which helped us to significantly advance our results and to substantially improve the manuscript.

\section{REFERENCES}

Alvarez, M. S., C. S. Vera, G. N. Kiladis, and B. Liebmann, 2015: Influence of the Madden Julian oscillation on precipitation and surface air temperature in South America. Climate Dyn., doi:10.1007/s00382-015-2581-6, in press.

Barreiro, M., P. Chang, and R. Saravanan, 2002: Variability of the South Atlantic convergence zone simulated by an atmospheric general circulation model. J. Climate, 15, 745-763, doi:10.1175/ 1520-0442(2002)015<0745:VOTSAC $>2.0 . C O ; 2$.

Benestad, R. E., I. Hanssen-Bauer, and D. Chen, 2008: EmpiricalStatistical Downscaling. World Scientific, 215 pp.

Carvalho, L. M. V, C. Jones, and M. A. F. Silva Dias, 2002: Intraseasonal large-scale circulations and mesoscale convective activity in tropical South America during the TRMM-LBA campaign. J. Geophys. Res., 107, 8042, doi:10.1029/ 2001JD000745.

— - _ and B. Liebmann, 2004: The South Atlantic convergence zone: Intensity, form, persistence, and relationships with intraseasonal to interannual activity and extreme rainfall. J. Climate, 17, 88-108, doi:10.1175/1520-0442(2004)017<0088: TSACZI $>2.0 . \mathrm{CO} ; 2$.

Chen, T.-S., S.-P. Weng, and S. Schubert, 1999: Maintenance of austral summertime upper-tropospheric circulation over tropical South America: The Bolivian high-Nordeste low system. J. Atmos. Sci., 56, 2081-2100, doi:10.1175/ 1520-0469(1999)056<2081:MOASUT > 2.0.CO;2.

Christensen, J. H., and Coauthors, 2007: Regional climate projections. Climate Change 2007: The Physical Science Basis, S. Solomon et al., Eds., Cambridge University Press, 847-940.

Cook, K., J. Hsieh, and S. Hagos, 2004: The Africa-South America intercontinental teleconnection. J. Climate, 17, 2851-2865, doi:10.1175/1520-0442(2004)017<2851:TAAIT>2.0.CO;2.

DeMaria, M., 1985: Linear response of a stratified tropical atmosphere to convective forcing. J. Atmos. Sci., 42, 1944-1959, doi:10.1175/1520-0469(1985)042<1944:LROAST>2.0.CO;2.

De Souza, E. B., and T. Ambrizzi, 2006: Modulation of the intraseasonal rainfall over tropical Brazil by the Madden-Julian oscillation. Int. J. Climatol., 26, 1759-1776, doi:10.1002/ joc.1331.

Diaz, A., and P. Aceituno, 2003: Atmospheric circulation anomalies during episodes of enhanced and reduced convective cloudiness over Uruguay. J. Climate, 16, 3171-3185, doi:10.1175/1520-0442(2003)016<3171:ACADEO>2.0.CO;2.

Figueroa, S. N., P. Satyamurty, and P. L. Da Silva Dias, 1995: Simulations of the summer circulation over the South American region with an eta coordinate model. J. Atmos. Sci., 52, 1573-1584, doi:10.1175/1520-0469(1995)052<1573:SOTSCO >2.0.CO;2. 
Gandu, A. W., and P. L. Silva Dias, 1998: Impact of tropical heat sources on the South American tropospheric upper circulation and subsidence. J. Geophys. Res., 103, 6001-6015, doi:10.1029/ 97JD03114.

Garreaud, R. D., 1999: Multiscale analysis of the summertime precipitation over the central Andes. Mon. Wea. Rev., 127, 901-921, doi:10.1175/1520-0493(1999)127<0901:MAOTSP>2.0.CO;2.

, 2000: Intraseasonal variability of moisture and rainfall over the South American Altiplano. Mon. Wea. Rev., 128, 3337-3346, doi:10.1175/1520-0493(2000)128<3337:IVOMAR > 2.0.CO;2.

- 2009: The Andes climate and weather. Adv. Geosci., 22, 3-11, doi:10.5194/adgeo-22-3-2009.

— , and P. Aceituno, 2001: Interannual rainfall variability over the South American Altiplano. J. Climate, 14, 2779-2789, doi:10.1175/1520-0442(2001)014<2779:IRVOTS >2.0.CO;2.

- M. Vuille, and A. C. Clement, 2003: The climate of the Altiplano: Observed current conditions and mechanisms of past changes. Palaeogeogr., Palaeoclimatol., Palaeoecol., 194, 5-22, doi:10.1016/S0031-0182(03)00269-4.

$\longrightarrow,-1$, R. Compagnucci, and J. Marengo, 2009: Present-day South American climate. Palaeogeogr. Palaeoclimatol. Palaeoecol., 281, 180-195, doi:10.1016/j.palaeo.2007.10.032.

Gutman, G. J., and W. S. Schwerdtfeger, 1965: The role of latent and sensible heat for the development of a high pressure system over the subtropical Andes in summer. Meteor. Rundsch., 18 (3), 69-75.

Hagos, S. M., and K. H. Cook, 2005: Influence of surface processes over Africa on the Atlantic marine ITCZ and South American precipitation. J. Climate, 18, 4993-5010, doi:10.1175/JCLI3586.1.

Haylock, M. R., and Coauthors, 2006: Trends in total and extreme South American rainfall in 1960-2000 and links with sea surface temperature. J. Climate, 19, 1490-1512, doi:10.1175/ JCLI3695.1.

Hofer, M., B. Marzeion, and T. Mölg, 2015: A statistical downscaling method for daily air temperature in data-sparse, glaciated mountain environments. Geosci. Model Dev., 8, 579593, doi:10.5194/gmd-8-579-2015.

Hurley, J. V., M. Vuille, D. R. Hardy, S. Burns, and L. G. Thompson, 2015: Cold air incursions, $\delta^{18} \mathrm{O}$ variability, and monsoon dynamics associated with snow days at Quelccaya Ice Cap, Peru. J. Geophys. Res. Atmos., 120, 7467-7487, doi:10.1002/2015JD023323.

Instituto Geofísico del Perú, 2005a: Atlas climatológico de precipitaciones y temperaturas en la Cuenca del Río Mantaro. CONAM, Lima, Perú, 107 pp. [Available online at http://www. met.igp.gob.pe/publicaciones/2000_2007/Atlas_Climatico.pdf.] 2005b: Vulnerabilidad actual y futura ante el cambio climático y medidas de adaptación en la Cuenca del Río Mantaro. CONAM, Lima, Perú, 104 pp. [Available online at http://www. met.igp.gob.pe/publicaciones/2000_2007/Vulnerabilidad_actual_ futura.pdf.]

Jones, C., and L. M. V. Carvalho, 2002: Active and break phases in the South American monsoon system. J. Climate, 15, 905-914, doi:10.1175/1520-0442(2002)015<0905: AABPIT $>2.0 . \mathrm{CO} ; 2$.

Kalnay, E., and Coauthors, 1996: The NCEP/NCAR 40-Year Reanalysis Project. Bull. Amer. Meteor. Soc., 77, 437-472, doi:10.1175/1520-0477(1996)077<0437:TNYRP>2.0.CO;2.

Kodama, Y., 1992: Large-scale common features of subtropical precipitation zones (the baiu frontal zone, the SPCZ and the SACZ) Part I: Characteristics of subtropical frontal zones. J. Meteor. Soc. Japan, 70 (4), 813-836.
, T. Sagawa, S. Ishida, and T. Yoshikane, 2012: Roles of the Brazilian Plateau in the formation of the SACZ.J. Climate, 25, 1745-1758, doi:10.1175/2011JCLI3785.1.

Kousky, V. E., 1979: Frontal influences on Northeast Brazil. Mon. Wea Rev., 107, 1140-1153, doi:10.1175/1520-0493(1979)107<1140: FIONB $>2.0 . \mathrm{CO} ; 2$.

—, and N. J. Ferreira, 1981: Interdiurnal surface pressure variations in Brazil: Their spatial distributions, origins, and effects. Mon. Wea. Rev., 109, 1999-2008, doi:10.1175/ 1520-0493(1981)109<1999:ISPVIB > 2.0.CO;2.

_ , and M. A. Gan, 1981: Upper tropospheric cyclonic vortices in the tropical South Atlantic. Tellus, 33A, 538-551, doi:10.1111/ j.2153-3490.1981.tb01780.x.

Lagos, P., Y. Silva, E. Nickl, and K. Mosquera, 2008: El Niñorelated precipitation variability in Peru. Adv. Geosci., 14 231-237, doi:10.5194/adgeo-14-231-2008.

Lavado Casimiro, W. S., J. Ronchail, D. Labat, J. C. Espinoza, and J. L. Guyot, 2012: Basin-scale analysis of rainfall and runoff in Peru (1969-2004): Pacific, Titicaca and Amazonas drainages. Hydrol. Sci. J., 57, 625-642, doi:10.1080/ 02626667.2012.672985.

, D. Labat, J. Ronchail, J. C. Espinoza, and J. L. Guyot, 2013: Trends in rainfall and temperature in the Peruvian AmazonAndes basin over the last 40 years (1965-2007). Hydrol. Processes, 41, 2944-2957, doi:10.1002/hyp.9418.

Lenters, J. D., and K. H. Cook, 1997: On the origin of the Bolivian high and related circulation features of the South American climate. J. Atmos. Sci., 54, 656-677, doi:10.1175/ 1520-0469(1997)054<0656:OTOOTB >2.0.CO;2.

Liebmann, B., and D. Allured, 2005: Daily precipitation grids for South America. Bull. Amer. Meteor. Soc., 86, 1567-1570, doi:10.1175/BAMS-86-11-1567.

—, G. N. Kiladis, J. A. Marengo, T. Ambrizzi, and J. D. Glick, 1999: Submonthly convective variability over South America and the South Atlantic convergence zone. J. Climate, 12, 1877-1891, doi:10.1175/1520-0442(1999)012<1877 SCVOSA $>2.0 . \mathrm{CO} ; 2$

,-- , D. Allured, C. S. Vera, C. Jones, L. M. V. Carvahlo, I. Bladé, and P. L. M. Gonzales, 2011: Mechanisms associated with large daily rainfall events in Northeast Brazil. J. Climate, 24, 376-396, doi:10.1175/2010JCLI3457.1.

Ma, H.-Y., X. Ji, J. D. Neelin, and C. R. Mechoso, 2011: Mechanisms for precipitation variability of the eastern Brazil/SACZ convective margin. J. Climate, 24, 3445-3456, doi:10.1175/ 2011JCLI4070.1.

Marengo, J. A., R. Jones, L. M. Alves, and M. C. Valverde, 2009: Future change of temperature and precipitation extremes in South America as derived from the PRECIS regional climate modeling system. Int. J. Climatol., 29, 2241-2255, doi:10.1002/ joc. 1863.

— , and Coauthors, 2012: Recent developments on the South American monsoon system. Int. J. Climatol., 32, 1-12, doi:10.1002/joc.2254.

Muza, M. N., L. M. V. Carvalho, C. Jones, and B. Liebmann, 2009 Intraseasonal and interannual variability of extreme dry and wet events over southeastern South America and the subtropical Atlantic during austral summer. J. Climate, 22, 16821699, doi:10.1175/2008JCLI2257.1.

Roe, G. H., 2005: Orographic precipitation. Annu. Rev. Earth Planet Sci., 33, 645-671, doi:10.1146/annurev.earth.33.092203.122541.

Silva, Y., K. Takahashi, and R. Chavez, 2008: Dry and wet rainy seasons in the Mantaro River basin (central Peruvian Andes). Adv. Geosci., 14, 261-264, doi:10.5194/adgeo-14-261-2008. 
Silva Dias, P. L., W. H. Schubert, and M. DeMaria, 1983: Largescale response of the tropical atmosphere to transient convection. J. Atmos. Sci., 40, 2689-2707, doi:10.1175/ 1520-0469(1983)040<2689:LSROTT>2.0.CO;2.

Spiegel, M. R., and L. J. Stephens, 1998: Statistical decision theory. 3rd ed. Theory and Problems of Statistics. McGraw-Hill, 216-241.

Vera, C., and Coauthors, 2006: Toward a unified view of the American monsoon systems. J. Climate, 19, 4977-5000, doi: 10.1175/JCLI3896.1.

Virji, H., 1981: A preliminary study of summertime tropospheric circulation patterns over South America estimated from cloud winds. Mon. Wea. Rev., 109, 599-612, doi:10.1175/ 1520-0493(1981)109<0599:APSOST>2.0.CO;2.

Vuille, M., 1999: Atmospheric circulation over the Bolivian Altiplano during dry and wet periods and extreme phases of the Southern Oscillation. Int. J. Climatol., 19, 1579-1600, doi:10.1002/ (SICI)1097-0088(19991130)19:14<1579::AID-JOC441>3.0.CO;2-N.

- and F. Keimig, 2004: Interannual variability of summertime convective cloudiness and precipitation in the central Andes derived from ISCCP-B3 data. J. Climate, 17, 3334-3348, doi:10.1175/1520-0442(2004)017<3334: IVOSCC $>2.0 . \mathrm{CO} ; 2$.

- R. S. Bradley, and F. Keimig, 2000: Interannual climate variability in the central Andes and its relation to tropical Pacific and Atlantic forcing. J. Geophys. Res., 105, $12447-$ 12 460, doi:10.1029/2000JD900134.

, - - M. Werner, and F. Keimig, 2003: 20th century climate change in the tropical Andes: Observations and model results. Climatic Change, 59, 75-99, doi:10.1023/ A:1024406427519.

Wilks, S. D., 2011: Statistical Methods in the Atmospheric Sciences. 3rd ed. International Geophysics Series, Vol. 100, Academic Press, 676 pp.

Xie, P., and P. A. Arkin, 1997: Global precipitation: A 17-year monthly analysis based on gauge observations, satellite estimates, and numerical model outputs. Bull. Amer. Meteor. Soc., 78, 2539-2558, doi:10.1175/1520-0477(1997)078<2539: GPAYMA $>2.0 . \mathrm{CO} ; 2$. 